\title{
A Study of Fungal Diseases Occurring on Stored Tomatoes of Balkhu Agriculture and Vegetable Market, Nepal
}

\section{Bimala Shakya $^{1} \bowtie$ and Hari Prasad Aryal ${ }^{2}$}

\author{
${ }^{1}$ Natural History Museum, Tribhuvan University, Swayambhu, Kathmandu, Nepal \\ ${ }^{2}$ Central Department of Botany, Tribhuvan University, Kirtipur, Nepal bimalashakya2012@gmail.com
}

\begin{abstract}
Tomatoes are one of the most widely produced and consumed vegetable in Nepal. Fungal pathogens deteriorate the quality and quantity of tomato and cause health hazards to the consumers as well as economic loss to the traders. This study was carried out to identify some fungal diseases associated with post-harvest deterioration of stored tomato fruits in Balkhu Agriculture and vegetable Market of Kathmandu, Nepal. Collected samples were cultured in Potato Dextrose Agar (PDA) media in complete randomized design. Fifteen species of fungi namely Alternaria alternata, A. solani, Aspergillus niger, Botrytis cinerea, Fulvum fulva, Colletotrichum truncatum, Curvularia spicifera, Fusarium oxysporum, Dipodascus geotrichum, Mucor mucedo, Penicillium chrysogenum, Phytophthora infestans, Boeremia exigua, Pythium aphanidermatum and Rhizopus stolonifer were identified. These were responsible for 14 different diseases of Alternaria fruit rot, Anthracnose, Black mold rot, Botrytis Bunch Rot, Damping off/ fruit rot, Drechslera mold, Fusarium rot, Mucor rot, Penicillum rot, Boeremia blight, Phytophthora rot, Rhizopus rot, Russet, and, Sour rot. The presence of these fungi and corresponding rot diseases on stored tomato indicates the need for management of fungi, farm sanitation and improved market in order to prevent field-to-storage transmission of pathogen.
\end{abstract}

Keywords: Consumers, health hazards, pathogen, post-harvest, traders 
108 Shakya and Aryal: A Study of Fungal Diseases Occurring on Stored Tomatoes ........

\section{INTRODUCTION}

Tomatoes (Lycopersicum esculentum L), one of the most popular and indivisible ingredients of human diet, are very popular use for vegetable and also in fruit. They are highly produced Solanaceous vegetable crop only after potato all over the world. Approximately 182.3 million tons of tomatoes are produced on 4.85 million ha. each year in the world (FAOSTAT, 2019).

Tomatoes are non-starchy and most significant source of dietary lycopene and ascorbic acid containing antioxidants, lycopene, ascorbic acid and phenols (George et al., 2004) together with vitamin-carbohydrates, proteins, fats and potassium. (Talvas et al., 2010). Lycopene is the pigment principally responsible for the characteristic deep-red color of ripe tomato fruits and its products. Lycopene being efficient quencher of singlet oxygen and free radicals provides protection against a broad range of epithelial cancers (Mascio et al., 1989). The consumption of tomato also reduces the risk of cardiovascular disease, osteoporosis, and ultraviolet lightinduced skin damage (e.g. sun burn) and cognitive dysfunction.

The crops were originated in western South America and Central America (Wamach, 2005) thereafter widely adapted to variable climatic conditions but still they are vulnerable to varieties of fungal diseases during production, harvesting, transportation and storage. In storage condition, they are often infected by several species of fungi such as Alternaria alternata, Collectrotrichum truncatum, Phytophthora infestans, Pythium aphanidermatum, Dipodascus geotrichum, Fusarium

oxysporum, Curvularia spicifera, Cladosporium sp., Penicillum chrysogenum, Mucor mucedo, Botrytis cinerea, etc., causing different diseases with distinct symptoms. They hinder the production of tomatoes leading to the severe economic loss. Moreover, they can lead to serious human health problem if consumed. Among them, tomato infected by Fusarium sp. is more dangerous to human health because they produce mycotoxins (Jofee, 1986; Nelson et al., 1990). Further, Alternaria is main decay causing organism of postharvest tomato fruit (Agrawal et al., 1950) and Alternaria rot has been considered most prevalent disease and causes huge losses to tomato thus making tomatoes unfit for consumption (Douglas, 1922). Alternaria solani, Rhizopus stolonifer, and Aspergillus niger are the most common pathogen 
and cause loss of $52.7 \%, 35.9 \%$ and $25 \%$ respectively in tomato fruit in Egypt (Mallek et. al., 1995). Fusarium rot caused by Fusarium oxysporum is reported as the most destructive on ripened tomato in the U.S. (Benyal et al., 2008). They can produce mycotoxin that is carcinogenic. Phytophthora rot is caused by Phytophthora infestans (Mills, 1940). These postharvest losses are more severe in developing than in developed countries (Enyiukwu et al., 2014). The magnitude of postharvest loses always vary from one country to another and one season to another and even one day to another (Mujib et al., 2007) so it is a challenging task for controlling these disease on tomatoes for researchers. Therefore, the aim of this study was to investigate the occurrence of fungi associated with tomatoes in stored conditions in agricultural and vegetable market of Balkhu (BAVM), Kathmandu, Nepal.

\section{Study area}

Balkhu Agriculture and Vegetable Market is one of the busiest trade and transit area located at southern side of Kathmandu valley and lies at an altitude of 1311 masl. It has a pleasant climate with average summer temperature ranging from $25^{\circ} \mathrm{C}$ to $35^{\circ} \mathrm{C}$ and $2^{\circ} \mathrm{C}$ to $12^{\circ} \mathrm{C}$ in winter. The average annual temperature is $18.1{ }^{\circ} \mathrm{C}$. About $1505 \mathrm{~mm}$ of precipitation falls annually (https://en.climate- data.org/). Tomatoes are brought to BAVM by the local traders from different places of Nepal. Among them, tomatoes brought from three places Bara district (Simraumgadh), Dhading district (Naubise), and Kavre district (Panauti) and stored in BAVM were chosen for investigation. Tomatoes brought from Simraumgadh of Bara district was considered as site A. Similarly, tomatoes brought from Naubise of Dhading district was consider as site B and tomatoes brought from Panauti of Kavre district was considered as site C. The tomatoes of Panauti was brought to BAVM from secondary source- Kalimati vegetable market, which is the center vegetable market of Kathmandu valley of Nepal.

Site $\mathrm{A}=$ Bara (Simraumgadh) is in Terai region of Nepal.

Site $\mathrm{B}=$ Dhading (Naubise) is in hilly region.

Site $\mathrm{C}=$ Kavre (Panauti) is also in hilly region of Nepal. 


\section{MATERIALS AND METHODS}

\section{Collection of Samples}

The infected tomatoes, 30 each, from three different study sites- A, B, and C brought and stored in BAVM were collected during November, 2019 to March 2020.

\section{Laboratory Analysis}

\section{Isolation}

The collected samples were kept in sterilized paper bags and brought to the Central Department of Botany, Tribhuvan University laboratory. Each of the samples was leveled and photographed. The Transverse Section (T.S.) of the infected part of the tomato was prepared and examined under the microscope for identification. For confirmation, the pathogens were separated from its host and grown in sterile culture medium plates. Plant pathogenic fungi were isolated by

planting surface sterilized bits of the infected plants tissue on sterilized media. For surface sterilization, four petri plates were arranged in a row near flame, under sterile condition. In the first petridish 70\% ethyl alcohol was filled and the rest three dishes were filled with sterilized water. Small bits of infected crops tissue were sterilized individually by placing them in ethanol for 1-2 minutes, and then transferred to sterile water in the next dish after 1-2 min. Then, they were moved to the next dish of sterile water. Thus, surface sterilized bit was aseptically transferred on the sterilized solidified Potato Dextrose Agar (PDA) medium in petri plates with the help of sterilized forceps.

\section{Culture}

The petri plates containing surface sterilized materiel on sterilized medium were sealed with paraffin tape and incubated in inverted position at $25^{\circ} \mathrm{C}$ for 72 hours for growth (Pathak, 1984).

\section{Subculture}


After 72 hours, the petri plates were taken out from the incubator and photographed. Then, they were brought to subculture process in which three inoculums dishes were prepared with the help of borer from 3 days old culture and transferred to three new petri plates filled with new PDA media separately. The petri plates were sealed with paraffin tapes and kept for incubation at $25^{\circ} \mathrm{C}$ for 10 days. Thus obtained pure culture was photographed.

\section{Identification}

The fungi were carefully transferred on the cello tape and mounted on the slide containing mixture of lacto phenol and cotton blue in order to stain the material. Thus prepared slides were examined under digital microscope (Olympus microscope Model No. CX22 Japan). The photographs were taken under immersion oil. The morphological characters of the fungi were studied under high power (10x $X$ 40x). The pathogen were identified with the help of diagnostic morphological characteristics seen under microscope as well as concerning standard literatures (ARX, 1974; Bessey, 1950; Gilman, 1957; Barnett, 1960; Ainsworth, et al., 1972), expertise and web surfing on online data base (Index Fungorum, Mycobank.org).

\section{RESULTS AND DISCUSSION}

Altogether 15 species of pathogenic fungi were identified from tomatoes brought to BAVM from three sites A, B and C. and stored in the same market. The varied fungal pathogens associated with the tomato diseases in each site are tabulated in table 1. Eight species (Alternaria alternata (Plate 1), Alternaria solani (Plate 2), Aspergillus niger (Plate 3), Collectrotrichum truncatum (Plate 6), Fusarium oxysporum (Plate 8), Dipodascus geotrichum (Plate 9), Mucor mucedo (Plate 10) and Rhizopus stolonifer (Plate 15) were obtained in all three sites of A, B and C. 12 species. Alternaria alternata (Plate 1), Alternaria solani (Plate 2), Aspergillus niger (Plate 3), Botrytis cinerea (Plate 4), Fulvum fulva (Plate 5), Colletotrichum truncatum (Plate 6), Curvularia spicifera (Plate 7), Fusarium oxysporum (Plate 8), Dipodascus geotrichum (Plate 9), Mucor mucedo (Plate 10), Pythium aphanidermatum (Plate 13) and Rhizopus stolonifer (Plate 15) were found in site A and B. Nine species Alternaria alternata (Plate1), Alternaria solani (Plate 2), Aspergillus niger (Plate 3), Colletotrichum truncatum (Plate6), Fusarium oxysporum (Plate 8), Dipodascus geotrichum (Plate 9), Mucor 
mucedo (Plate 10), Penicillum chrysogenum (Plate 11) and Rhizopus stolonifer (Plate 15) were common in site B and C. And eight species (Alternaria alternata (Plate 1), Alternaria solani (Plate 2), Aspergillus niger (Plate 3), Colletotrichum truncatum (Plate 6), Fusarium oxysporum (Plate 8), Dipodascus geotrichum (Plate 9), Mucor mucedo (Plate 10) and Rhizopus stolonifer (Plate 15) were common in site A and C. Similarly, on the basis of frequency of occurrence of the

species, eight dominant (D) species were found in all three sites A, B and C. Five moderate (M) species Botrytis cinerea (Plate 4), Fulvum fulva (Plate 5), Curvularia spicifera (Plate 7), Penicillum chrysogenum (Plate 11) and Pythium aphanidermatum (Plate 13) were found in two study sites and two rare (R) species Boeremia exigua (Plate 12) and Phytophthora infestans (Plate 14) found in only one of the study site B (table 1).

It is found that among all 15 species 12 species (except Boeremia exigua, Penicillium chrysogenum and Phytophthora infestans) were recorded from site A, whereas all 15 species were recorded from site B and 9 species (Alternaria alternata, Alternaria solani, Aspergillus niger, Colletotrichum truncatum, Fusarium oxysporum, Dipodascus geotrichum, Mucor mucedo, Penicillum chrysogenum and Rhizopus stolonifer were obtained from site $\mathrm{C}$.

\section{TABLE 1. Comparative occurrence of fungal pathogens and their corresponding diseases.}

\begin{tabular}{|c|l|c|c|c|c|l|}
\hline S. N. & \multicolumn{1}{|c|}{ Name of fungi } & Site A & Site B & Site C & Category & \multicolumn{1}{|c|}{ Diseases } \\
\hline 1. & Alternaria alternata & + & + & + & $\mathrm{D} *$ & Black mold rot \\
\hline 2. & Alternaria solani & + & + & + & $\mathrm{D}$ & Alternaria rot \\
\hline 3. & Aspergillus niger & + & + & + & $\mathrm{D}$ & Black mold rot \\
\hline 4. & Botrytis cinerea & + & + & - & $\mathrm{M} * *$ & Grey mole rot \\
\hline 5. & Cladosporium flavum & + & + & - & $\mathrm{M}$ & Scab/ Cladosporium rot \\
\hline 6. & Colletotrichum truncatum & + & + & + & $\mathrm{D}$ & Anthracnose rot \\
\hline 7. & Curvularia spicifera & + & + & - & $\mathrm{M}$ & Drechslera mold rot \\
\hline 8. & Fusarium oxysporum & + & + & + & $\mathrm{D}$ & Fusarium rot \\
\hline 9. & Dipodascus geotrichum & + & + & + & $\mathrm{D}$ & Sour rot \\
\hline
\end{tabular}




\begin{tabular}{|c|l|c|c|c|c|l|}
\hline 10. & Mucor mucedo & + & + & + & $\mathrm{D}$ & Mucor rot \\
\hline 11. & Penicillum chrysogenum & - & + & + & $\mathrm{M}$ & Penicillium rot \\
\hline 12. & Boeremia exigua & - & + & - & $\mathrm{R} * * *$ & Boeremia rot \\
\hline 13. & Pythium aphanidermatum & + & + & - & $\mathrm{M}$ & Pythium rot \\
\hline 14. & Phytophthora infestans & - & + & - & $\mathrm{R}$ & Phytophthora rot \\
\hline 15. & Rhizopus stolonifer & + & + & + & $\mathrm{D}$ & Rhizopus rot \\
\hline \multicolumn{2}{|c|}{ Total numbers of species } & 12 & 15 & 9 & & \\
\hline \multicolumn{2}{|c|}{ Numbers of species in } \\
percentage
\end{tabular}

*Dominant, ${ }^{* *}$ Moderate, ${ }^{* * *}$ Rare.

In present study, the maximum numbers (15 species) of fungi were recorded from site B (100\%) then site A, 12 species $(80 \%)$. Site C, had least in number i.e. 9 species $(60 \%)$ as depicted in table 1.
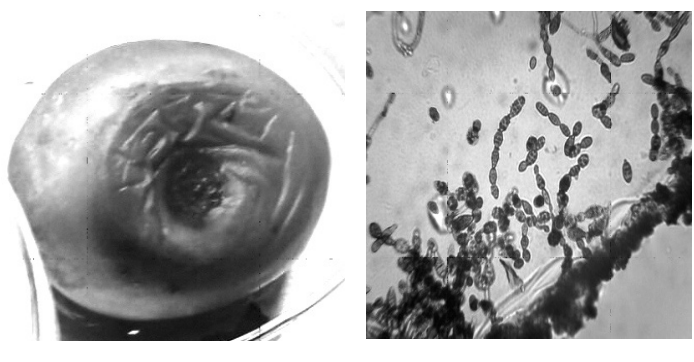

1. Alternaria alternata
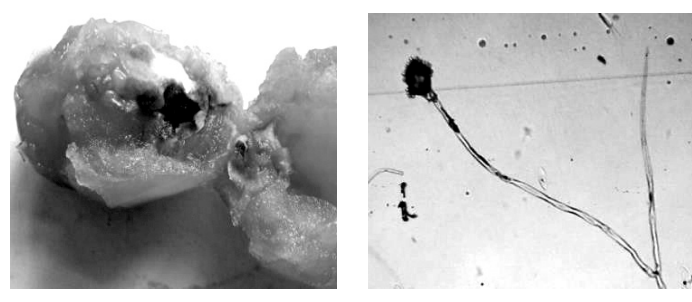

3. Aspergillus niger
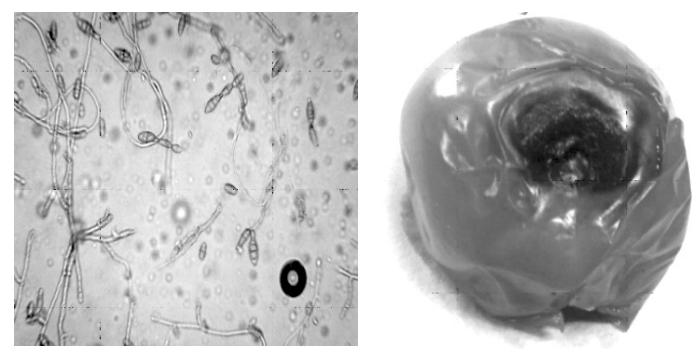

2. Alternaria solani
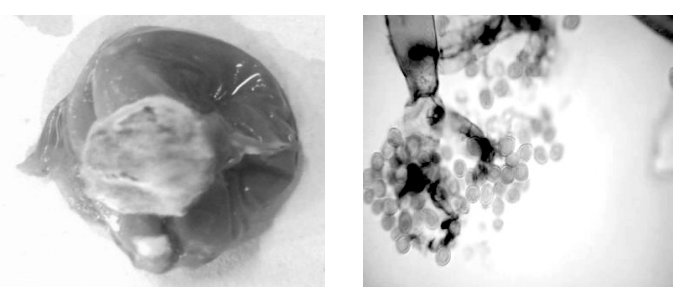

4. Botrytis cinera 

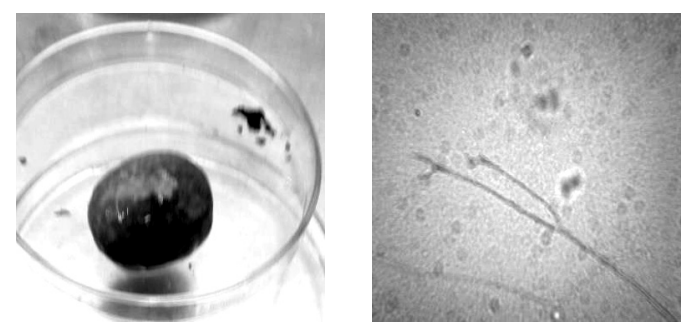

5.Cladosporium sp

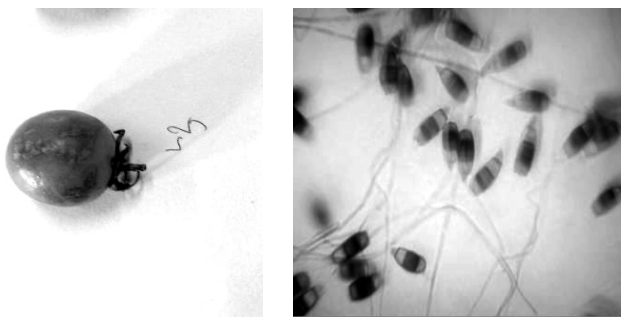

7. Curvularia spicifera
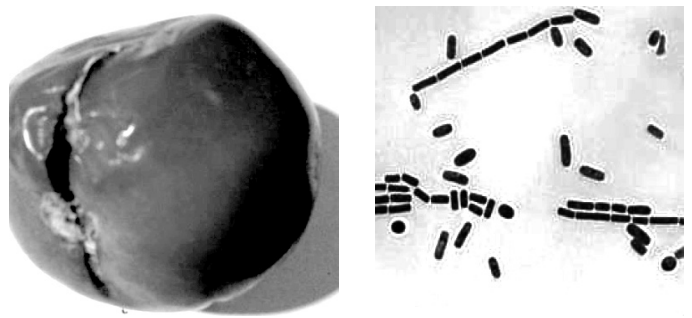

9. Dipodascus geotrichum
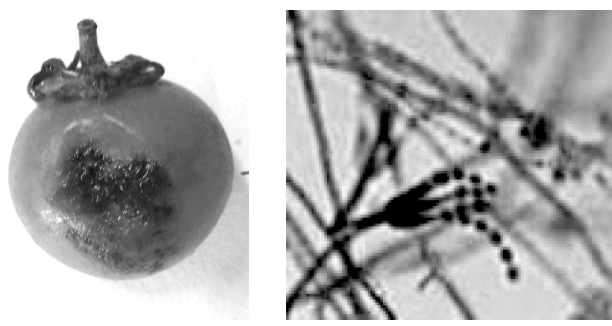

11.Penicillum chrysogenum
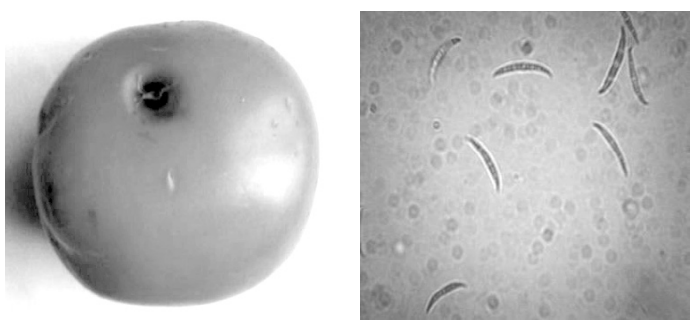

6. Colletotrichum truncatum
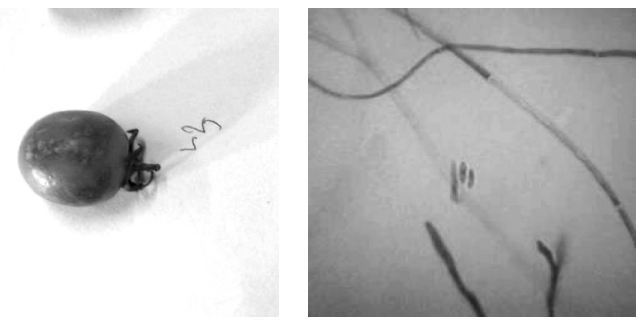

8. Fusarium oxysporum
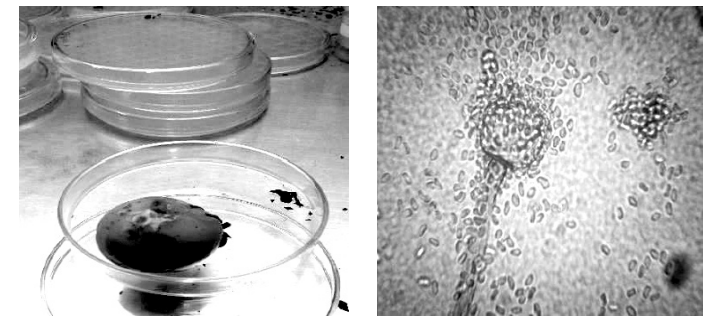

10. Mucor meucedo
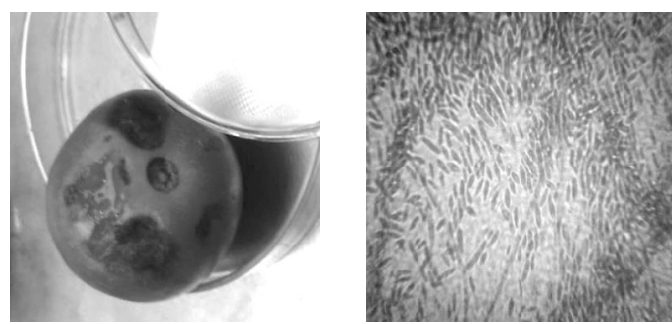

12. Boeremia exigua 

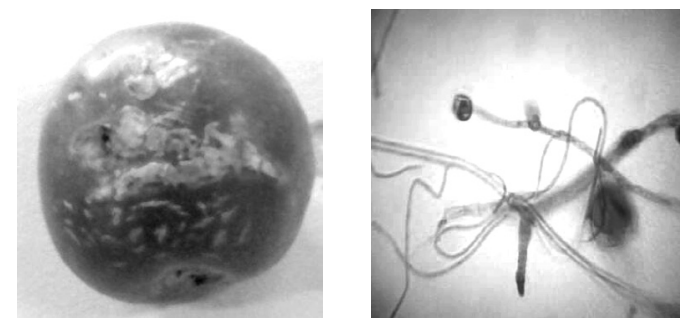

13.Pythium aphanidermatum

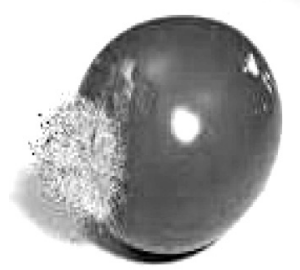

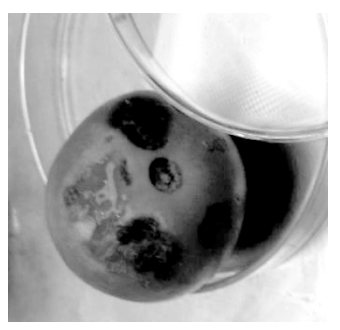

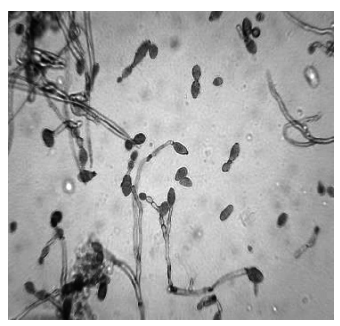

14.Phytophthora infestan

15. Rhizopus stolonifer

PHOTO PLATES 1-15. Disease symptoms and corresponding pathogens obtained during the investigation.

Occurrence of pathogens on tomatoes basically depends upon the sources of tomato and fungal bio-aerosols of market environment where they are exposed (Kakde \& Kakde, 2012). Temperature, moisture and bioaerosol are the major factor for producing infection on tomatoes. The stored tomatoes became highly susceptible due to wound occur (Sajad et al., 2017). In present study, availability of 15 pathogenic fungal species was varied in different study sites (table 1). Same number of species was reported by Manandher et al. (2017). They reported 15 species of fungi from 342 tomato crop samples along with other solanaceous crops collected from different part of the country. They reported Alternaria alternata, Alternaria solani and Phytophthora infestans similar to this investigation. They also reported Cladosporium sp., Collectrotrichum sp., Fusarium sp., Phoma sp. and Pythium sp. that cause fruit rot and other diseases on crop plants.

Of the 15 reported species, eight were most common and dominant (table 1). Similar results was reported from Mumbai, India by Rodrigues \& Kakde (2019). They mentioned that $A$. niger, 
A. flavus, A. alternata, Collectrotrichum sp., Rhizopus sp. and F. oxysporum were the most common and frequently isolated. While Botrytis cinerea, Penicillum digitatum, P. chrysogenum, Boeremia sp., Cladosporium sp. were the least fungi they isolated during investigation which was almost similar to this investigation. And similar report was given in Nagpur, India by Kakde \& Kakde (2012). They reported that the fungi like Aspergillus, Penicillum, Cladosporium, Fusarium and Alternaria were the most frequent associated fungi isolated from vegetable and fruits. Similarly, Shrestha (2005) had included four tomato pathogens e.g. Alternaria sp., Colletotrichum sp., Stemphyllum sp. and Verticillum sp. These species were the most prevalent in the commercial market and also found to be responsible for most of the decay of vegetables and fruits during storage.

All of the species reported in present investigation are responsible for 14 different corresponding diseases (table 1). Most of them are respective rot disease. Wani (2011) reported nine fungal rot diseases on postharvest tomato, among them seven were similar reported in present investigation that are Alternaria rot, Anthracnose rot, Mucor rot, Blue mole rot, Phytophthora rot, Phomopsis blight, Fusarium rot caused by respective pathogen of Alternaria solani, Colletotrichum truncatum, Mucor Mucedo, Penicillum sp., Phytophthora infestans, Boeremia destructive and Fusarium oxysporum respectively. Similar to this investigation, Massoud (2013) also isolated Aspergillus, Acremonium, Alternaria, Fusarium, and Penicillum in Lycopersicum esculentum from Aswan, Egypt. Chigoziri, et al. (2018) also reported Aspergillus flavus, Colletotrichum capcisi, and Pythium sp. from Nigeria.

Bartz et al. (2017) described 11 fungal post-harvest diseases along with bacterial postharvest diseases found in Florida. Among them, nine of the fungal rot diseases namely Fusarium, Phoma, Anthracnose, Cladosporium, Grey mole, Phytophthora, Rhizopus, Black mold and Sour rot, similar to results obtained in present investigation.

Thus, during this investigation, 11 fungal rot diseases of Alternaria, Anthracnose, Black mold, Fusarium, Mucor, Penicillium (Blue mold rot), Phytophthora, Pythium, Phomopsis blight, Rhizopus and sour rot were described more or less by different researchers from Nepal and abroad. Kohl et al. (2015) only reported scab epidemic in Dabrowice on Cortland Apple. 
The tomatoes in Balkhu market were imported from Dhadhing, Bara, Kalimati as well as from different places of the country. It is recommended to grow Srijana variety in the context of Bara district (Gurung et al., 2020). Local farmers have been supplying vegetables produced in Dhading to market in Balkhu of Kathmandu (Shrestha, 2017). Some similar pathogenic fungi were seen in the dominant species in all three study sites, as they were transmitted from fields with suitable temperature for their growth. Some dissimilarity was also observed that must be due to verities of tomatoes and market environment where opportunist fungi grow. Both biological and physiological damage during the harvest and transportation phase coupled with large amount of water and soft endocarp makes tomato more susceptible to spoilage by fungi (Asan \& Ekmeki, 2002; Sajad et al., 2017). The tomatoes brought from Dhading district were local tomatoes having thin epidermis with soft endocarp which made it easier for the fungus to infect the tomatoes may be the reason for more infection found in tomatoes from Dhading district.

Till now, many researches on tomato diseases have been carried out by NARC in order to produce resistant varieties. Most of them were concentrated on late blight. For a long time, NARC has researched to produce late blight resistant tomato caused by Phytophthora infestans. NARC has been involved in hybrid breeding of tomato with special focus on developing resistant FIs on BW and LB Srijana. Some of the new hybrids are promising in this year and among them to superior tomato hybrid lines; HRA 14x 7 and HRA20XHRD2 have been submitted to national seed board for releasing (NARC, 2020). In co-ordination varietal evaluation at Khumaltar, cultivar STMO2 was least affected by late blight disease whereas CLN2545B, HRD109, STM02 and Pusa ruby were least affected by Septoria disease (NARC, 2019). However, investigations on stored tomato diseases caused by other pathogenic fungi haven't been carried out so far. Thus, it is the first investigation depicting occurrence of fungal pathogens and associated diseases on post-harvest tomatoes in Nepal.

Most of the fungi obtained in this investigation were soil fungi that are transmitted from field or during transportation and storage. Local tomatoes are more prone to infection by fungi present in bio-aerosol of market environment. Directly or indirectly fungi infected fruits and vegetables sold by traders cause ill consequences on the 
consumer's health. Therefore, control measures shoul be implied by farmers and traders. Late blight disease can be managed by rational use of bio-pesticides and fungicides, krilaxyl and dithane M-45 (Shrestha \& Ashley, 2007).

Disease of fruits rots are generally caused by opportunistic pathogen that normally lives on plant debris. However, these opportunists can infect tissue that are wounded or exposed or diseased (Bertz et al., 2017). Thus fruit rots can be minimized in field by the employment of strict sanitation measures along with careful handling during transportation and storage time. Resistant variety should be used by farmers. Traders should use strict sanitation measures in shops. They should keep out bruised, rotten and infected fruits separate and dispose them accordingly so that the fresh fruits won't get infected.

Since human pathogen do not visibly affect the fruit their presence may be unknown at the time of packaging and marketing (Bertz et al. 2017) which necessitates consumer's knowledge about the symptoms of diseases in order to identify the diseased tomatoes. In addition, well- managed, sanitized, well-facilitated vegetable market should be provided by local government as services for local people. Therefore, this study provides the necessary awareness of fungal disease in public. It may also help to minimize losses caused by postharvest fungal diseases to local traders and will be helpful to build up concrete strategy for management of postharvest fungal disease of tomato. As the study of diseases on tomatoes is important and concerned with public health, it is very necessary to carry out further research works on tomato diseases in future.

\section{ACKNOWLEDGEMENTS}

The authors would like to acknowledge Office of Dean, Institute of Science and Technology, Tribhuvan University, Kirtipur, Kathmandu, Nepal for providing research grant to conduct this study. The authors are obliged to the Central Department of Botany, Tribhuvan University for providing laboratory facilities. The Natural History Museum, Swayambhu, Tribhuvan University is thanked for facilitated the administrative asset. Sincere thanks are extended to the local traders of the study area for providing valuable information and materials for the investigation. 


\section{REFERENCES}

AGRAWAL, G P; NERNE, K G; BELIRAM, R (1950) Fungi causing plant disease at Jabalpur, M P. Proceeding of National Academy Science, India 13: 310-315.

AINSWORTH, G C; SPARROW, F K; SUSSMAN, A S (Editors) (1972) The Fungi. An Advanced Treatise. A Taxonomic Review with Keys: Basidiomycetes and Lower Fungi. XXII, 504 S., 85 Abb. 1 Tafel. New York-London Academic Press; Vol. IV B: pp1-621.

ASAN, A; EKMEKI, S (2002) Contribution to the colonial and morphological characteristics of some Aspergillus species isolated from soil. Journal of Faculty of Science 25: 21-139.

ARX VON, J A (1981). The genera of fungi sporulating in pure culture. 99 fig. Verlag J. Cramer, Vaduz . Preis: 120, DM; 424pp. ( $3^{\text {rd }}$ edition).

BANYAL, D K; MANKOTIA, V; STIGHA, S K (2008) Integrated management of tomato collar rot caused by Selerotitini rolfsii. Journal of Mycology and Plant Pathology 38: 165-167.

BARNETT, H L (1960) Illustrate genera of imperfect fungi. Burgess Publishing Co., Minneapolis, USA; 225pp ( $2^{\text {nd }}$ edition).

BARTZ, STEVEN; SARGENT, A; MICHAEL, M (2017) Guide to identifying and controlling postharvest tomato diseases in Florida. IFAS extension, University of Florida. Available at: http://www.edis.ifas.ufl.edu.

BESSEY, E A (1950) Morphology and taxonomy of fungi. Vikas Publishing House Pvt. Ltd. New Delhi, India; 791pp.

CHIGOZIRI, E; JOHN O, NAM, N S (2018) Fungi associated with postharvest rot and seedling infection of tomato (Solanum lycopersicion) from Otukpo and Makurdi Local Government Areas of Benue State, Nigeria. In Proceeding of 36th annual conference of horticulture society of Nigeria (Hortson). Faculty of Agriculture, Shabu Lafia Campus, Nigeria, pp 641- 645.

CLIMATE DATA.ORG (2020) Kathmandu Climate (Nepal). Availabe at: https://en.climate- data.org/asia/nepal/.

DOUGLAS, B (1922) A new alternaria spot of tomatoes in California. Phylopalhology 12: $146-148$. 
ENYIUKWU, D N; AWURUM, A N; NWANERI, J A (2014) Efficacy of plant derived pesticides in the control of myco-induced postharvest rots of tubers and agricultural products.Net Journal of Agricultural Science 2 (1): 30-46.

FAOSTAT (2019) Food and Agriculture Data. Avilable at: http://www.fao.org/ faostat/en/\#home.

GEORGE, B; KAUR, C; KHURDIYA, D S; KAPOOR, H C (2004) Antioxidants in tomato (Lycopersicum esculentum L.) as a function of genotype. Food Chemistry 84: 45-51. DOI: 10.1016/S0308-8146(03)00165-1.

GILMAN, J C (1957) A manual of soil fungi. The Iowa State Univ. Press. Ames, Iowa, USA; $450 \mathrm{pp}$. ( $2^{\text {nd }}$ edition).

GURUNG, S; ADHIKARI, P; GIRI, K; GOTAME, T P, SHRESTHA, S L (2020) Growth and yield performance of hybrid tomato (Solanum lycopersicum L.) lines at Parwanipur, Bara, Nepal. Journal of Agriculture and Natural Resources 3(1): 180-189. DOI: https://doi.org/10.3126/janr.v3i1.27166.

JOFEE, A Z (1986) Fusarium species: their biology and toxicology. John Wiley \& Sons Ltd., Chichester, USA; 588pp.

KAKDE, U B; KAKDE, H U (2012) Incidence of post-harvest disease and airborne fungal spores in a vegetable market. An International Journal Acta Botanica Croatica 71 (1): 147-57.

KOHL J, SCHEER C, HOLB IJ, MASNY S., MOLHOEK W (2015) Toward an integrated biological control by Cladosporium cladosporiodes H39 in apple scab (Venturia inequaluis) management. Plant Disease. 99(4) 535- 543.

MALLEK, A Y; HEMIDA, S K; BAGY, M K (1995) Studies associated with tomato fruit and effectiveness of some commercial fungicides against three pathogen. Mycopathologia: 130 (2): 109-126.

MANANDHAR, C; BADIY, S; MANANDHAR, S; PANTA, B; MOHATO, B N (2017) Identification of different diseases on solanaceae crops from different location of the country. In GAUTAM, IP; SUBEDI, GD; GOTAME, TP; SHRESTHA, SL; BHATTARAI, DR;

UPADHAYA, K P (eds) Proc. Ninth National Horticulture Workshop. May 31-June 1, 2017, NARC, HRD, Khumaltar, Lalitpur, Nepal. pp253-261. 
MASCIO, P; KAISER, S; SEIS, H (1989) Lycopene as the most efficient biological carotenoid singlet oxygen quencher. Archives of Biochemistry and Biophysics 274(2): $532-538$.

MASSOUD, M S (2013) Survey of fungal diseases of some vegetables and fruits in Aswan, EGYPT. Journal of Pharmacy and Biological Sciences 6(3): 39-42.

MILLS, W R (1940) Phytophthora infestans on tomato. Journal of Phytopathology 30: $830-839$.

MUJIB, U R; NAUSHAD, K; INAYATULLAH, J (2007) Postharvest losses of tomato crop. Sarhad Journal of Agriculture 23 (4): 1279.

NARC (2019) Annual Report (2017-18). Nepal Agricultural Research Council, Khumaltar, Lalitpur, Nepal.

NARC (2020) Annual Report (2019-020). Nepal Agricultural Research Council, Khumaltar, Lalitpur, Nepal.

NELSON, P E; BURGESS, L W; SUMMERELL, B A (1990) Some morphological and physiological characters of Fusarium species in sections liseola and elegans and similar new species. Mycologia 82: 99-106.

PATHAK, V N (1984) Laboratory manual of plant pathology Oxford and IBH Publishing Company,New Delhi, India. (2 $2^{\text {nd }}$ edition).

RODRIGUES, B B; KAKDE, U B (2019) Post-harvest fungi associated with Solanum Lycopercisum (tomato) fruit collected from different market of Mumbai. Online International Interdisciplinary Research Journal 9: 52-60.

SAJAD, A M; JAMALUDDIN, A H (2017) Fungi associated with the spoilage of postharvest tomato fruits and their frequency of occurrences in different markets of Jabalpur, Madhya- Pradesh, India. International Journal of Current Research and Reviews 9(5): 12-15.

SHRESTHA, K; ASHELY, R (2007) Integrated disease management of tomato late blight. Nepal Agricultural Research Journal 8: 67-76.

SHRESTHA, R (2015) In vitro management of four tomato fungal pathogens using plant extracts and fermented products. M.Sc. Dissertation. Central Department of Botany, Tribhuvan University, Kirtipur, Kathmandu, Nepal. 
SHRESTHA, S (2017) Low production makes vegetables dearer in Dhading. My Republica. Retrieved from https://myrepublica.nagariknetwork.com/news/ low-production-makes- vegetables-dearer-in-dhading/

TALVAS, J; CARIS-VEYRAT, C; GUY, L; RAMBEAU, M; LYAN, B; MINETQUINARD, LOBACCARO JA, VASSON M, GEORGE S, MAZUR A (2010) Differential effects of lycopene consumed in tomato paste and lycopene in the form of purified extract on target genes of cancer prostatic cells. American Journal of Clinical nutrition 91: 1716-1724.

WAMACHE, A (2005) Vegetable seeds handbook. Regina seeds Seminis. Bizone Ltd., Nairobi Kenya; pp23-25.

WANI, A H (2011) An overview of the fungal rot of tomato. Journal of Mycology and Pathology 9(1): 33-38. 